\title{
A commentary on the US policies for efficient large scale renewable energy storage systems: focus on carbon storage cycles
}

Authors: Emre Gençer ${ }^{1}$, Rakesh Agrawal $^{1} *$

\author{
Affiliations: \\ ${ }^{1}$ School of Chemical Engineering, Purdue University, West Lafayette, IN-47907, USA \\ *correspondence to agrawalr@ purdue.edu
}

\begin{abstract}
The inevitable depletion of fossil resources and increasing atmospheric greenhouse gas concentrations demonstrate the need for renewable energy conversion technologies for a sustainable economy. Intermittencies and variability in availability of renewable energy sources are the challenges for uninterrupted energy supply, which can be overcome by large scale energy storage facilities. Pumped hydroelectric energy storage is an efficient but a very low energy density energy storage method that dominates the current energy storage market with 96\% share. We first present a recently developed potential solution for large scale efficient and dense energy storage: closed loop carbon storage cycles and a specific example dimethyl ether storage cycle. We then discuss the relevant US energy storage regulations, policy initiatives, their status, and potential modifications that will contribute to the invention and implementation of novel energy storage systems.
\end{abstract}

Keywords: Solar energy, renewable energy, energy storage, electricity, carbon storage cycles 


\section{Introduction}

The global energy sector is predominantly dependent on fossil resources. In 2014, approximately $87 \%$ of the world energy consumption was provided by fossil resources (oil, natural gas and coal) (EIA, 2015). Although the natural gas share in the energy mix is highly sensitive to the natural gas price and carbon tax from gas production (Bistline, 2014), discoveries of shale oil and shale gas will likely postpone the inevitable end of fossil resources. Yet, in less than 100 years fossil fuel reserves will be substantially diminished (EIA, 2015) and replaced by renewable energy sources. Finding the best strategies for utilization of the remaining resources is critical for a smooth transition to a sustainable economy. Furthermore, continuous increase in atmospheric greenhouse gases $(\mathrm{GHG})$ mainly carbon dioxide $\left(\mathrm{CO}_{2}\right)$, which is one of the main causes of global warming, is also a severe consequence of extensive utilization of fossil resources (Dlugokencky and Tans, 2013).

In $2014,67 \%$ of the electricity generation in the U.S. was provided by fossil resources, primarily coal and natural gas with respective contributions of $39 \%$ and $27 \%$. The $19 \%$ nuclear energy share was followed by $13 \%$ total renewable power, for which the predominant sources were hydroelectricity by $7 \%$ and wind by $4.4 \%$. The solar electricity share was only $0.4 \%$ (EIA, 2015).

All of these facts point to the importance and urgency of finding, developing and implementing sustainable energy systems. Among renewable energy sources, solar energy is the most promising due to its tremendous potential. Solar irradiance on the earth's surface in 1 hour is comparable to the annual global energy consumption (Lewis and Nocera, 2006). A future solar economy vision anticipates fulfillment of human needs from solar energy (Agrawal and Mallapragada, 2010). However, despite its enormous potential, the share of the solar energy in 
the energy mix has only recently started to increase. Though the growth curve of solar energy is presently very steep, its current share in the global primary energy consumption is less than $1 \%$ (EIA, 2015). Yet, solar energy is expected to play a critical role in meeting future energy demand. The long-term predictions show that share of solar energy in the global primary energy supply mix will exceed $10 \%$ by 2050 (Timilsina et al., 2012). The large scale implementation of renewable energy sources depends on many factors, such as on the consumer side: i) willingness to pay the price for green power (Aldy et al., 2012; Burtraw et al., 2013), and ii) changing consumption habits (Sanquist et al., 2012). And on the technological side, i) the effect of lower capacity factor compared to fossil fuel power plants (Lesser and Su, 2008); ii) the ability to meet the ancillary services (Cappers et al., 2013); iii) the availability of infrastructure (Delucchi and Jacobson, 2011), and iv) the reliability of the renewable power (Burtraw et al., 2013). However, besides all these factors, limitations such as variations and intermittencies in availability create a real challenge for grid stability for high renewable energy penetration. Intermittencies can be overcome by proper energy management for low and medium penetration (Schaber et al., 2012); however, energy storage is indispensable for renewable energy penetration above $80 \%$ (Denholm and Hand, 2011).

A major barrier to widespread implementation of solar technologies is the inadequacy of the current energy storage systems to overcome intermittencies (Timilsina et al., 2012). For energy storage, the harnessed solar energy must be first transformed into a storable form and, subsequently, used to generate electricity. To give a perspective, on average the solar energy in the U.S. is available for only one-fifth of a day (Lewis and Nocera, 2006). To supply an average of 100MW solar electric power over a twenty-four hour cycle, electricity equivalent energy must 
be stored for the remaining four-fifths of the day, which means $\sim 2 \mathrm{GWh}$ of electricity equivalent energy storage is needed on a daily basis.

Energy storage systems are also important for the fossil fuel based electricity production sector. Currently, electricity is supplied by two classes of power plants: base load power plants that have constant output, and peaking power plants that supply electricity to overcome peaks and spikes in consumer demand. A base load energy storage system that meets the peak electricity demand may eliminate the need to operate peaking power plants. An integrated coal-fueled power plant and compressed air energy storage system has been shown to successfully follow load variations without significant effect on efficiency (Nease and Adams, 2014). Hence, fossil fuel power plants can be operated at almost constant power output at their optimum operating conditions. Yet, the design and control of any energy storage system integrated with either renewable or fossil generation system requires careful consideration to prevent suboptimal operation (Morandin et al., 2012; Siirola and Edgar, 2012).

\subsection{Background on U.S. energy policies}

Current U.S. energy policy initiatives can be divided into three main categories: fuel economy regulations, regulations to decrease GHG emissions, and regulations to increase renewable energy share. Fuel economy regulations like new CAFE (Corporate Average Fuel Economy) regulations (2011) may change the expected consumption patterns of remaining fossil fuel resources that are anticipated to be used as bridge solutions (Dauenhauer and Huber, 2014; Gençer et al., 2014b; Mallapragada et al., 2014; Onel et al., 2015).

President Obama and the U.S. Environmental Protection Agency have announced the Clean Power Plan, which is an important step in reducing carbon pollution form power plants that aims 
to define state-based standards to reduce carbon pollution across the U.S. in agreement with each state's energy mix. The plan envisions reducing carbon pollution from the power sector $32 \%$ below 2005 levels by the year 2030 (EPA, 2015). Clean Air Interstate Rule (CAIR), Cross-State Air Pollutant Rule (CSAPR), National Emissions Standards for Hazardous Air Pollutants (NESHAP) are other examples of legislation and regulations on GHG level control. Targets to increase renewable energy share include 10-40\% renewable energy inclusion by 2015 and onwards. Renewable Portfolio Standard (RPS) or similar law that applies to 30 of the states and the District of Columbia has set these targets. The aforementioned policies will definitely increase the renewable energy share in the U.S. energy consumption, but they should be supported by suitable energy storage regulations to make the initiative stronger.

\subsection{Large scale energy storage systems and their global penetration}

Current wind and solar power integration, which is mainly in the introductory phase, corresponds to a small share of renewable energy in the energy mix. However, to move to the next phase, which includes integration of fluctuating renewable energy sources in large scale, the grid stability concern should be met (Frisari and Stadelmann, 2015; Lund et al., 2012; Orecchini and Santiangeli, 2011). A reliable robust large scale energy storage system can bring stability and reliability to the renewable energy sector.

An energy storage system for renewable energy resources should receive electricity and renewable energy in other forms (if available) and deliver electricity. High roundtrip storage efficiency, high storage capacity and high storage density are the important features for a suitable energy storage method (Chen et al., 2009). Since large scale energy storage systems require high investments, they should provide benefits, such as ensuring grid stability (Lund et al., 2012). 
Furthermore, storage systems must be long lasting and non-degradable over time (Chen et al., 2009). The current large-scale energy storage options are pumped hydroelectric, electro-chemical (batteries), electro-mechanical (compressed air energy storage, CAES), gaseous hydrogen and liquid hydrogen storage (Barnes and Levine, 2011). A comparison of current large-scale storage options in terms of storage efficiency and storage density is given in Figure 1. Energy storage options such as flywheels and supercapacitors can deliver electricity rapidly, which is critical to maintaining grid stability. These systems are not truly large scale energy storage options, but likely to be implemented in tandem with suitable large scale energy systems for uninterrupted power supply (Chen et al., 2009).

Pumped hydroelectric and batteries are the most efficient storage methods ( 80\%). Pumped hydroelectric and compressed air storage have very low storage densities: $\sim 5 \cdot 10^{-5} \mathrm{GJ} / \mathrm{m}^{3}$ and $\sim 3 \cdot 10^{-2} \mathrm{GJ} / \mathrm{m}^{3}$, respectively. Batteries have higher storage densities $\left(\sim 1-1.3 \mathrm{GJ} / \mathrm{m}^{3}\right)$, but still an order of magnitude lower than that of the $\mathrm{H}_{2}$ storage $\left(\sim 3.2-6.5 \mathrm{GJ} / \mathrm{m}^{3}\right)(\mathrm{EPRI}, 2010)$. Furthermore, CAES needs a heat source during delivery mode. Although heat can be supplied from a variety of energy sources, the common practice is the use of hydrocarbon fuels. Short lifetime, issues of disposal and dependence on rare earth elements for batteries, and heat loss from thermal storage especially for CSP systems are examples of concerns (Timilsina et al., 2012).

The global energy storage projects are summarized in Figure 2. The overall rated power of operational, under construction, contracted and under repair of a total of 1206 energy storage projects is $184 \mathrm{GW}$ (DOE, 2013). More than $96 \%$ of this rated power is associated with pumped hydroelectric energy storage. Molten salt thermal storage systems have the second largest total rated power of $2.6 \mathrm{GW}$ (1.4\% of the total), and as seen from Figure 2(a), approximately half of 
that capacity is under construction. The total rated power of electro-chemical and electromechanical storage options is close to $2 \mathrm{GW}$, but there are few new large scale projects. The number of projects and the average rated power for each storage method is depicted in Figure 2(b). The average rated power for pumped hydroelectric systems for a total of 341 projects is $520 \mathrm{MW}$, while for electro-chemical energy storage the average rated power is $1.4 \mathrm{MW}$ for a total of 376 projects. The average rated power for molten salt thermal storage and electro-mechanical storage is $65 \mathrm{MW}$ and $24 \mathrm{MW}$, respectively.

The distribution of energy storage projects for countries is shown in Figure 3. The total energy storage rated power of China, U.S. and Japan accounts for $\sim 50 \%$ of the global energy storage capacity. Nine countries have energy storage systems that are larger than $5 \mathrm{GW}$, and they account for $\sim 74 \%$ of the global energy storage capacity.

The energy storage capacity alone does not provide insight for the strategies of countries in terms of energy storage implementation. Hence, we calculated the energy storage-to-renewable power generation capacity ratio and energy storage-to-total power generation capacity ratio and summarized the results in Figure 4. The U.S., France, Italy and Spain have similar energy storage-to-renewable power generation capacity ratio. Japan has the largest energy storage to both renewable power and total power generation capacities. China, India and Germany have low energy storage-to-renewable power generation capacity ratio, which can be associated with high hydroelectricity generation in China and India and very large renewable power generation capacity (76GW (WB, 2014), 45\% of total power generation capacity) of Germany.

Briefly, energy storage capacity in the world is low when compared to the total power generation capacity. With increasing energy demand, in particular for electricity, and as the share of 
renewable energy sources increases, large scale energy storage capacity will need to increase considerably. Yet, the current energy storage sector is dominated by pumped hydroelectric systems, which require suitable geographical locations and store energy with very low energy density.

We present here a potential storage solution, the carbon storage cycle, for high efficiency GWhlevel energy storage, details of dimethyl ether storage cycle integrated with solar power generation as an example carbon storage system, along with a discussion of the relevant U.S. regulation and policy initiatives. Alternative chemical storage options, such as carbon storage cycles, have a role to play for energy storage at large scales and must be supported in the federally funded research and development portfolio. However, current U.S. policy initiatives neglect this potentially promising family of large scale energy storage option.

\section{A potential large scale energy storage solution: carbon fuel storage}

The synthesis of carbon fuels (such as alkanes, alcohols, and ethers) is an attractive large scale energy storage solution because carbon fuels have high volumetric energy density (e.g. gasoline is $\sim 32 \mathrm{GJ} / \mathrm{m}^{3}$ ), can be efficiently converted to electricity (50-70\%) (Hassmann, 2001), and can be easily handled by the well-established technology and infrastructure available for their utilization (Graves et al., 2011; Pearson et al., 2012).

Synthesis of various carbon fuels, including methane (Bierschenk et al., 2011; Pearson et al., 2012; Sun et al., 2012), methanol (Olah et al., 2006; Rihko-Struckmann et al., 2010), dimethyl ether (Olah et al., 2006; Sun et al., 2012), and diesel (Agrawal et al., 2007), using renewable energy sources has been proposed and demonstrated to be viable computationally (Agrawal and 
Singh, 2009; Eason and Cremaschi, 2014; Gassner and Maréchal, 2009) as well as experimentally (Lebarbier et al., 2012; Parsell et al., 2015; Venkatakrishnan et al., 2015).

However, the open-loop nature, that is, the carbon and hydrogen molecules used to synthesize carbon fuel are released to the atmosphere after their usage, makes these options less attractive for energy storage applications (Agrawal et al., 2007; Graves et al., 2011; Keith, 2012; Mallapragada et al., 2013) because (i) once released $\mathrm{CO}_{2}$ extraction from the atmosphere or even industrial exhausts demands high energy input (Pearson et al., 2012; Rochelle, 2009); (ii) the availability of biomass and land to grow biomass is limited (Searchinger et al., 2008); and (iii) sustainably available biomass should be primarily used to produce renewable transportation fuel (Mallapragada et al., 2013; Singh et al., 2010). Yet, closed-loop processes where the carbon dioxide formed during power generation is recirculated within the process are more consistent with the cyclical nature of energy storage and renewable energy usage, since the net $\mathrm{CO}_{2}$ emissions from closed-loop processes are nearly zero (Bierschenk et al., 2011; Sridhar and Gottmann, 2008).

\subsection{Carbon storage cycles}

The carbon storage cycle, shown in Figure 5, is a closed-loop carbon fuel process that consists of cyclic transformation of a carbon fuel and carbon dioxide (Al-musleh et al., 2014a, b). The carbon storage cycle is a high storage efficiency, high storage density process with zero GHG emission, which can be a good solution for large scale applications.

The process cycle consists of two modes: storage mode (when renewable energy is available), and delivery mode (when renewable energy is not available). During storage mode renewable energy in the form of electricity and heat (if available) is converted into a suitable carbon fuel 
(CF) (R-1) in the phase to be stored using the liquid carbon dioxide that was stored in the delivery mode of the cycle.

$\mathrm{xCO}_{2}+\mathrm{yH}_{2} \rightarrow \mathrm{CF}+\mathrm{zH}_{2} \mathrm{O} \quad \mathrm{R}-1$

The delivery mode provides electricity in the absence of renewable energy by combusting the carbon fuel (R-2), and captures and liquefies carbon dioxide produced in the course of combustion.

$\mathrm{CF}+(0.5 \mathrm{y}) \mathrm{O}_{2} \rightarrow \mathrm{xCO}_{2}+(\mathrm{y}-\mathrm{z}) \mathrm{H}_{2} \mathrm{O} \quad \mathrm{R}-2$

Determining the most attractive carbon fuel in terms of the storage efficiency and storage density is very important to determine the operating range of the system. For that purpose, different carbon fuel alternatives, such as methane, methanol, dimethyl ether (DME), have been investigated based on their ability to retain the greater fraction of the hydrogen energy used for its synthesis, their volumetric energy density, and energy per carbon atom. Detailed simulation of attractive candidates, methane, methanol and DME has been performed (Al-musleh et al., 2014b; Gençer et al., 2014a). Details of DME storage cycle, one of the top carbon storage cycles, are briefly presented in the next section to highlight the principles and performance of carbon storage cycles and demonstrate the promise of chemical storage techniques.

\subsection{Example carbon storage cycle: DME storage cycle}

The DME storage cycle shown in Figure 6, is a closed loop storage cycle that consists of cyclic transformation of DME molecule and carbon dioxide. The analysis has been performed for a solar energy storage system with the assumptions that solar energy is available as heat and as electricity for one-fifth of the day (4.8 hours), and that during the storage mode, the process 
produces sufficient amount of DME to supply $140 \mathrm{MW}$ of electric power for 19.2 hours of the delivery mode (Gençer et al., 2014a). The DME storage cycle consists of a storage mode (when solar energy is available) and a delivery mode (when solar energy is not available). The results are extendable to other renewable power generation systems like wind power, as well as fossil fuel power plants.

Storage mode consists of five main process steps: Hydrogen production by solid oxide electrolysis cell (SOEC), $\mathrm{CO}_{2}$ to DME conversion using $\mathrm{CO}_{2}$ stored during delivery mode and produced hydrogen, methanol to DME conversion, removal of excess water that is produced as a byproduct of DME synthesis reaction, DME purification and liquefaction that uses the refrigeration released during the evaporation of liquid carbon dioxide $\left(-56^{\circ} \mathrm{C}\right)$.

The delivery mode provides the electricity requirement for the remaining 19.2 hours of operation using the stored liquid DME. For the simulation, the outlet power is assumed to be constant and equal to $\sim 140 \mathrm{MW}$. Delivery mode consists of four main process steps: DME vaporization, $\mathrm{CO}_{2}$ purification and liquefaction for which refrigeration released during the DME evaporation ($38^{\circ} \mathrm{C}$ ) is used to minimize the energy requirement and mixed refrigerants are used to supply additional refrigeration, excess water removal, DME reforming and power generation via solid oxide fuel cell (SOFC).

Direct DME production route from carbon dioxide $\left(\mathrm{CO}_{2}\right)$ and solar-derived $\mathrm{H}_{2}$ is preferred for the cycle since stored $\mathrm{CO}_{2}$ can be directly used and fewer processing steps will decrease the process energy losses, hence improving overall process efficiency. DME storage cycle shown in Figure 6 can be run in different DME purity levels: DME, DME/Methanol mixture, DME/Methanol/Water mixture. Different storage options allow for balancing the process 
efficiency against storage volume (Figure 1). Technical details of the DME cycle are available in (Gençer et al., 2014a).

\subsubsection{Performance of DME cycle}

To compare the storage performance with the current storage options, storage efficiency is calculated by the ratio of total net power output to net energy input. The storage efficiency for the pure DME case is calculated to be $53.8 \%$, and the total storage volume (liquid $\mathrm{CO}_{2}$ and liquid DME) is $1558 \mathrm{~m}^{3}$ (equivalent of $\sim 6.2 \mathrm{GJ} / \mathrm{m}^{3}$ ). For the DME/MeOH and DME/MeOH/W cases the efficiency is estimated to be $54.1 \%$ and $56.5 \%$, respectively. The estimated total storage volumes for $\mathrm{DME} / \mathrm{MeOH}$ and $\mathrm{DME} / \mathrm{MeOH} / \mathrm{W}$ are $1817 \mathrm{~m}^{3}$ (equivalent of $\sim 5.3 \mathrm{GJ} / \mathrm{m}^{3}$ ) and $2743 \mathrm{~m}^{3}$ (equivalent of $\sim 3.5 \mathrm{GJ} / \mathrm{m}^{3}$ ), respectively. The proposed DME storage option compares well with the existing large-scale storage options in terms of both energy density and storage efficiency (Figure 1). Estimated DME storage efficiency is higher than that of CAES and $\mathrm{H}_{2}$ storage options and is superior in terms of the energy density criteria, having the highest energy density. For large scale energy storage (GWh-level), the energy density is a significant issue; hence the DME cycle is a promising storage system. As in development of any new technology, the modeling results must be validated by experiments at different scales. SOC (solid oxide cells), combining both fuel (SOFC) and electrolyzer (SOEC) mode in one, is a relatively new technology that has prompted interest due to the high achievable conversion efficiencies and advantages of using a single equipment continuously for multiple objectives (Klotz et al., 2014). The potential degradation and recovery of SOCs due to the long-term operation and operating mode changes have been studied (Lindahl et al., 2014; Malzbender et al., 2012; Sohal et al., 2009; Tietz et al., 2013) and are under continuous development for commercialization. 


\section{Current U.S. policies and regulations}

An energy bottleneck is eventually expected due to the limited availability of fossil resources, and its current ever increasing use is leading to emission of record high levels of atmospheric GHG. The possible futuristic clean and non-fossil resource scenarios like solar economy vision have already been proposed (Agrawal and Mallapragada, 2010; Bolton, 1978; Lewis and Nocera, 2006). A large number of research institutions are working on developing transition solutions for a renewable energy driven economy. However, the impact of scientific advancements is limited, especially in the renewable energy storage arena by its supporting legislative actions. The current energy policies and regulations are summarized in Table 1. There are two main driving forces behind the legislative actions in the U.S.: energy independence, and environmental considerations. The objective of the Energy Independence and Security Act of 2007 (EISA) is "to move the United States toward greater energy independence and security, to increase the production of clean renewable fuels, to protect consumers, to increase the efficiency of products, buildings, and vehicles, to promote research on and deploy greenhouse gas capture and storage options, and to improve the energy performance of the Federal Government, and for other purposes."

In the United States Energy Storage Competitiveness Act of 2007 (ESCA), section 641 of EISA, describes "the initiative to maintain competitive posture of U.S. in energy storage systems for electric drive vehicles, stationary applications, and electricity transmission and distribution." As a part of the plan, an Energy Storage Advisory Council (Council) was formed as a subcommittee of electricity advisory committee (EAC). Every five years the council is expected to develop a five-year plan for U.S. storage research and assess the progress of the plan every two years. Before discussing the details of the current assessment report (2014), we note that chemical 
storage systems (e.g., carbon fuel like DME as a storage medium) are not explicitly stated as a storage system in ESCA. The only chemical storage system present in ESCA as of 2007 is hydrogen storage. Reports (EAC, 2012, 2014) detail the progress made since 2008. As a part of the American Recovery and Reinvestment Act of 2009 (ARRA), DOE provided \$185 million of matching to launch $\$ 772$ million worth of storage projects. $62.3 \%$ of DOE storage funding has been spent for the installment of CAES with 450MW total storage capacity and battery storage with 57MW total storage capacity. The other ARRA-funded energy storage technologies are as follows, with the corresponding total storage capacities given in parentheses: frequency regulation ancillary services (20MW), distributed storage for grid support $(7.5 \mathrm{MW})$ and demonstration of promising storage technologies $(2.8 \mathrm{MW})$. The current low price of natural gas enables meeting peak demand and managing variable resources with minimal cost, which renders storage investment in the short term needless. The near term recommendations of the report encourage basic electrochemical storage research. The mid-term recommendations include funding new storage technology projects that will enhance the grid performance and show the advantages of use of renewable energy resources.

Finally, The STORAGE Bill of 2009 and STORAGE 2010 Bill were the only recent efforts to support energy storage investments. The STORAGE Bill of 2009 was introduced on May 20, 2009 and reintroduced on December 3, 2009. STORAGE 2010 Bill, introduced on July 20, 2010, proposed amending the Internal Revenue Code of 1986 to provide for an energy investment credit for energy storage property connected to the grid, and for other purposes (2010). The qualifying energy storage property is described to be directly connected to the grid and to receive electricity for store energy and convert the stored energy to electricity. In the list of the storage options, chemical storage other than hydrogen storage is not listed explicitly. There is a section 
especially emphasizing that the energy storage property should enable the improvement in integration of renewable resources into the grid. From the description of the facility the minimum storage capacity is stated as $1 \mathrm{MW}$ power supply for at least one hour, which includes small scale storages. In the minimum capacity section (iii) the expected roundtrip energy storage efficiency is greater than or equal to 80 percent. When this statement is interpreted in the light of energy storage options described in the previous section, pumped hydro-storage and Li-on batteries are the only storage options that can meet this criterion. STORAGE Bill 2010 was not enacted.

In May 2013, the Storage Technology for Renewable and Green Energy Bill of 2013 (STORAGE 2013 Bill) was introduced, but it was not enacted. One of the important changes in STORAGE 2013 Bill from the STORAGE 2010 Bill was in the Minimum Capacity section, where clause (iii), stating the roundtrip energy storage efficiency, is removed and the definition of minimum capacity is modified from 20 kilowatt hours to 5 kilowatt hours. The removal of the storage efficiency clause makes it possible to support other storage options such as carbon storage cycles.

Finally, in the recent Clean Power Plan Rule, energy storage is stated as a measure to not directly adjust the $\mathrm{CO}_{2}$ emission rate, but an enabler to increase the renewable energy share in the energy mix. Especially, large scale energy storage, referred to as utility scale energy storage, is stated to potentially increase the grid penetration of renewable energy generation (EPA, 2015).

\section{Conclusions and policy implications}

The current energy sector is highly dependent on fossil resources. The eventual depletion of fossil resources and high levels of atmospheric GHG concentrations argue for the development 
of sustainable strategies to maintain the energy supply. Ultimately, renewable energy sources will dominate the energy sector and power production.

For uninterrupted power supply from renewable energy sources, renewable power production technologies must be integrated with suitable energy storage methods. For large scale applications, GWh levels, roundtrip storage efficiency and storage density become critical. We have discussed carbon fuel storage options, an efficient large scale closed-loop energy storage system, carbon storage cycle and a particular example DME storage cycle. When compared with current storage technologies, the presented carbon storage cycles perform well in terms of storage density and storage efficiency. The roundtrip storage efficiency of the presented system is higher than CAES and hydrogen storage systems. Batteries and pumped hydro storage systems have higher roundtrip storage efficiency than that of DME storage cycle. However, the storage density of pumped hydro storage is incredibly low and its application limited by geographical availability. The storage density of batteries is about an order of magnitude lower than DME storage.

When the current policies (summarized in Table 1) are investigated, there is no explicit interest in chemical energy storage options like carbon storage cycles, which is apparently promising compared to the current preferred storage systems. All the government funding on storage system research and development and also on storage investments is valuable and should be continued; however, an important storage alternative is omitted from the scope of the fundedprojects. There is no limitation in the latest storage act, STORAGE 2013 Act, on storage efficiency, but still chemical storage options other than hydrogen storage are not explicitly stated. Alternative chemical storage options, such as the ones discussed here, have a role to play for energy storage at large scales (GWh levels). It is highly recommended that unconventional 
storage technologies be supported and included in the federally funded research and development portfolio.

\section{Acknowledgment}

Research supported as part of the Center for Direct Catalytic Conversion of Biomass to Biofuels, an Energy Frontier Research Center funded by U.S. Department of Energy, Office of Science, Basic Energy Sciences (BES), under Award \#, DE-SC SC0000997; by the National Science Foundation Solar Economy IGERT (0903670-DGE), and Purdue University Global Policy Research Institute (GPRI). 


\section{References}

American Energy Security: Building a bridge to energy independence and to a sustainable energy future, The Southern States Energy Board Norcross, Georgia (2006)

2010. Storage Technology for Renewableand Green Energy Act of 2010.

Agrawal, R., Mallapragada, D.S., 2010. Chemical Engineering in a Solar Energy-Driven Sustainable Future. AIChE Journal 56, 2762-2768.

Agrawal, R., Singh, N.R., 2009. Synergistic Routes to Liquid Fuel for a Petroleum deprived future. AIChE Journal 55, 1898-1905.

Agrawal, R., Singh, N.R., Ribeiro, F.H., Delgass, W.N., 2007. Sustainable fuel for the transportation sector. Proceedings of the National Academy of Sciences of the United States of America 104, 48284833.

Al-musleh, E.I., Mallapragada, D.S., Agrawal, R., 2014a. Continuous baseload renewable power using chemical refrigeration cycles. Computers \& Chemical Engineering 71, 591-601.

Al-musleh, E.I., Mallapragada, D.S., Agrawal, R., 2014b. Continuous power supply from a baseload renewable power plant. Applied Energy 122, 83-93.

Aldy, J., Kotchen, M., Leiserowitz, A., 2012. Willingness to pay and political support for a US national clean energy standard. Nature Climate Change 2, 596-599.

Barnes, F.S., Levine, J.G., 2011. Large Energy Storage Systems Handbook. CRC Press.

Bierschenk, D.M., Wilson, J.R., Barnett, S.A., 2011. High efficiency electrical energy storage using a methane-oxygen solid oxide cell. Energy \& Environmental Science 4, 944-951.

Bistline, J., 2014. Natural gas, uncertainty, and climate policy in the US electric power sector. Energy Policy 74, 433-442.

Bolton, J.R., 1978. Solar Fuels. Science 202, 705-711.

Burtraw, D., Palmer, K., Paul, A., Beasley, B., Woerman, M., 2013. Reliability in the US electricity industry under new environmental regulations. Energy Policy 62, 1078-1091.

Cappers, P., MacDonald, J., Goldman, C., Ma, O., 2013. An assessment of market and policy barriers for demand response providing ancillary services in US electricity markets. Energy Policy 62, 1031-1039.

Chen, H., Cong, T.N., Yang, W., Tan, C., Li, Y., Ding, Y., 2009. Progress in electrical energy storage system: A critical review. Progress in Natural Science 19, 291-312.

Dauenhauer, P., Huber, G., 2014. Biomass at the shale gas crossroads. Green Chemistry 16, 382-383.

Delucchi, M., Jacobson, M., 2011. Providing all global energy with wind, water, and solar power, Part II: Reliability, system and transmission costs, and policies. Energy Policy 39, 1170-1190.

Denholm, P., Hand, M., 2011. Grid flexibility and storage required to achieve very high penetration of variable renewable electricity. Energy Policy 39, 1817-1830.

Dlugokencky, E., Tans, P., 2013. NOAA/ESRL Trends in Atmospheric Carbon Dioxide. U.S. Department of Commerce National Oceanic and Atmospheric Administration (NOAA) Earth System Research Laboratory (ESRL) Boulder, CO.

DOE, 2013. DOE Global Energy Storage Database. U.S. Department of Energy (DOE), Sandia National Laoratories.

EAC, 2012. 2012 Storage Report: Progress and Prospects Recommendations for the U.S. Department of Energy. The Electricity Advisory Committee.

EAC, 2014. 2014 Storage Plan Assessment Recommendations for the U.S. Department of Energy. The Electricity Advisory Committee.

Eason, J., Cremaschi, S., 2014. A multi-objective superstructure optimization approach to biofeedstocksto-biofuels systems design. Biomass \& Bioenergy 63, 64-75.

EIA, 2015. Annual Energy Outlook 2015 with projections to 2040. U.S. Energy Information Administration.

EPA, 2015. Carbon Pollution Emission Guidelines for Existing Stationary Sources: Electric Utility Generating Units. Environmental Protection Agency. 
EPRI, 2010. Electricity Energy Storage Technology Options: A White Paper Primer on Applications, Costs and Benefits. Electric Power Research Institute, Palo Alto, CA.

Frisari, G., Stadelmann, M., 2015. De-risking concentrated solar power in emerging markets: The role of policies and international finance institutions. Energy Policy 82, 12-22.

Gassner, M., Maréchal, F., 2009. Thermo-economic process model for thermochemical production of Synthetic Natural Gas (SNG) from lignocellulosic biomass. Biomass and Bioenergy 33, 1587-1604.

Gençer, E., Al-musleh, E., Mallapragada, D., Agrawal, R., 2014a. Uninterrupted Renewable Power through Chemical Storage Cycles. Current Opinion in Chemical Engineering 5, 29-36.

Gençer, E., Mallapragada, D.S., Tawarmalani, M., Agrawal, R., 2014b. Synergistic Biomass and Natural Gas Conversion to Liquid Fuel with Reduced $\mathrm{CO}_{2}$ Emissions, 8th International Conference on Foundations of Computer-Aided Process Design. Elsevier, Cle Elum, WA, pp. 525-530.

Graves, C., Ebbesen, S.D., Mogensen, M., Lackner, K.S., 2011. Sustainable hydrocarbon fuels by recycling $\mathrm{CO} 2$ and $\mathrm{H} 2 \mathrm{O}$ with renewable or nuclear energy. Renewable and Sustainable Energy Reviews $15,1-23$.

Hassmann, K., 2001. SOFC Power Plants, the Siemens-Westinghouse Approach. Fuel Cells 1, 78-84.

Keith, D.W., 2012. Why Capture CO2 from the Atmosphere? Science 325, 1654-1655.

Klotz, D., Leonide, A., Weber, A., Ivers-Tiffee, E., 2014. Electrochemical model for SOFC and SOEC mode predicting performance and efficiency. International Journal of Hydrogen Energy 39, 20844-20849. Lebarbier, V., Dagle, R., Kovarik, L., Adarme, J., King, D., Palo, D., 2012. Synthesis of methanol and dimethyl ether from syngas over Pd/ZnO/Al2O3 catalysts. Catalysis Science \& Technology 2, 2116-2127. Lesser, J., Su, X., 2008. Design of an economically efficient feed-in tariff structure for renewable energy development. Energy Policy 36, 981-990.

Lewis, N.S., Nocera, D.G., 2006. Powering the planet: Chemical challenges in solar energy utilization. Proceedings of the National Academy of Sciences of the United States of America 103, 15729-15735.

Lindahl, P.A., Hu, X., Wold, J., Cornachione, M., Shaw, S.R., 2014. Solid Oxide Fuel Cell Degradation, Recovery, and Control via Electrical Terminals. Proceedings of the ASME 2014 12th International Conference on Fuel Cell Science.

Lund, H., Andersen, A., Ostergaard, P., Mathiesen, B., Connolly, D., 2012. From electricity smart grids to smart energy systems - A market operation based approach and understanding. Energy 42, 96-102.

Mallapragada, D., Duan, G., Agrawal, R., 2014. From shale gas to renewable energy based transportation solutions. Energy Policy 67, 499-507.

Mallapragada, D.S., Singh, N.R., Curteanu, V., Agrawal, R., 2013. Sun-to-Fuel Assessment of Routes for Fixing CO2 as Liquid Fuel. Industrial \& Engineering Chemistry Research 52, 5136-5144.

Malzbender, J., Batfalsky, P., Vassen, R., Shemet, V., Tietz, F., 2012. Component interactions after longterm operation of an SOFC stack with LSM cathode. Journal of Power Sources 201, 196-203.

Morandin, M., Maréchal, F., Mercangöz, M., Buchter, F., 2012. Conceptual design of a thermo-electrical energy storage system based on heat integration of thermodynamic cycles - Part A: Methodology and base case. Energy 45, 375-385.

Nease, J., Adams, T., 2014. Coal-fuelled systems for peaking power with $100 \%$ CO2 capture through integration of solid oxide fuel cells with compressed air energy storage. Journal of Power Sources 251, 92-107.

Olah, G.A., Goeppert, A., Prakash, G.K.S., 2006. Beyond Oil and Gas: The Methanol Economy. WileyVCH Verlag Gmbh and Co. KGaA.

Onel, O., Niziolek, A., Elia, J., Baliban, R., Floudas, C., 2015. Biomass and Natural Gas to Liquid Transportation Fuels and Olefins (BGTL+C2_C4): Process Synthesis and Global Optimization. Industrial \& Engineering Chemistry Research 54, 359-385.

Orecchini, F., Santiangeli, A., 2011. Beyond smart grids - The need of intelligent energy networks for a higher global efficiency through energy vectors integration. International Journal of Hydrogen Energy 36, 8126-8133.

Parsell, T., Yohe, S., Degenstein, J., Jarrell, T., Klein, I., Gencer, E., Hewetson, B., Hurt, M., Kim, J., Choudhari, H., Saha, B., Meilan, R., Mosier, N., Ribeiro, F., Delgass, W., Chapple, C., Kenttamaa, H., 
Agrawal, R., Abu-Omar, M., 2015. A synergistic biorefinery based on catalytic conversion of lignin prior to cellulose starting from lignocellulosic biomass. Green Chemistry 17, 1492-1499.

Pearson, R.J., Eisaman, M.D., Turner, J.W.G., Edwards, P.P., Zheng, J., Kuznetsov, V.L., Littau, K.A., di Marco, L., Taylor, S.R.G., 2012. Energy Storage via Carbon-Neutral Fuels Made From CO2, Water, and Renewable Energy. Proceedings of the IEEE 100, 440-460.

Rihko-Struckmann, L.K., Peschel, A., Hanke-Rauschenbach, R., Sundmacher, K., 2010. Assessment of Methanol Synthesis Utilizing Exhaust CO2 for Chemical Storage of Electrical Energy. Industrial \& Engineering Chemistry Research 49, 11073-11078.

Rochelle, G.T., 2009. Amine Scrubbing for CO2 Capture. Science 325, 1652-1654.

Sanquist, T., Orr, H., Shui, B., Bittner, A., 2012. Lifestyle factors in U.S. residential electricity consumption. Energy Policy 42, 354-364.

Schaber, K., Steinke, F., Hamacher, T., 2012. Transmission grid extensions for the integration of variable renewable energies in Europe: Who benefits where? Energy Policy 43, 123-135.

Searchinger, T., Heimlich, R., Houghton, R.A., Dong, F., Elobeid, A., Fabiosa, J., Tokgoz, S., Hayes, D., Yu, T.-H., 2008. Use of U.S. Croplands for Biofuels Increases Greenhouse Gases Through Emissions from Land-Use Change. Science 319, 1238-1240.

Siirola, J., Edgar, T., 2012. Process energy systems: Control, economic, and sustainability objectives. Computers \& Chemical Engineering 47, 134-144.

Singh, N.R., Delgass, W.N., Ribeiro, F.H., Agrawal, R., 2010. Estimation of Liquid Fuel Yields from Biomass. Environmental Science \& Technology 44, 5298-5305.

Sohal, M.S., O'Brien, J.E., Stoots, C.M., Herring, J.S., Hartvigsen, J.J., Larsen, D., Elangovan, S., Carter, J.D., Sharma, V.I., Yildiz, B., 2009. Critical Causes of Degradation in Integrated Laboratory Scale Cells During High-Temperature Electrolysis. Idaho National Laboratory, p. 65.

Sridhar, K., Gottmann, M., 2008. Combined energy storage and fuel generation with reversible fuel cells, USA.

Sun, X., Chen, M., Jensen, S.H., Ebbesen, S.D., Graves, C., Mogensen, M., 2012. Thermodynamic analysis of synthetic hydrocarbon fuel production in pressurized solid oxide electrolysis cells. International Journal of Hydrogen Energy 37, 17101-17110.

Tietz, F., Sebold, D., Brisse, A., Schefold, J., 2013. Degradation phenomena in a solid oxide electrolysis cell after $9000 \mathrm{~h}$ of operation. Journal of Power Sources 223, 129-135.

Timilsina, G., Kurdgelashvili, L., Narbel, P., 2012. Solar energy: Markets, economics and policies. Renewable \& Sustainable Energy Reviews 16, 449-465.

Venkatakrishnan, V.K., Delgass, W.N., Ribeiro, F.H., Agrawal, R., 2015. Oxygen removal from intact biomass to produce liquid fuel range hydrocarbons via fast-hydropyrolysis and vapor-phase catalytic hydrodeoxygenation. Green Chemistry 17, 178-183.

WB, 2014. World Development Indicators 2014. World Bank. 


\section{Figure Captions}

Figure 1 Energy Storage Options Comparison, Hydro: Pumped Hydroelectric Storage, CAES: Compressed Air Energy Storage, Na-S: Sodium-sulfur Battery, Li-on: Lithium-ion Battery, GH2: Gaseous Hydrogen Storage, LH2: Liquid Hydrogen Storage (EPRI, 2010) and DME: DME storage cycle with high purity DME storage, DME/MeOH: DME storage cycle with storage of DME and methanol mixture, DME/MeOH/W: DME storage cycle with the storage of DME, methanol mixture and methanol, water mixture.

Figure 2 Summary of global energy storage projects (DOE, 2013). (a) Total Rated Power, (b) Average Rated Power and Number of Projects.

Figure 3 Total Energy Storage Rated Power by Country including under construction and under repair energy storage projects. (DOE, 2013)

Figure 4 Energy storage to power generation capacity ratios for eight countries with the largest energy storage rated power capacity. Energy storage to power generation capacities for renewable power (triangle) and total power (diamond) are shown on the left axis; total power generation capacity is presented by a bar and shown on the right axis.

Figure 5 Simplified flow diagram of closed loop carbon storage cycle

Figure 6 Flow diagram of storage and delivery modes of DME storage cycle. SOEC: Solid Oxide Electrolysis Cell Delivery Mode, SOFC: Solid Oxide Fuel Cell. 


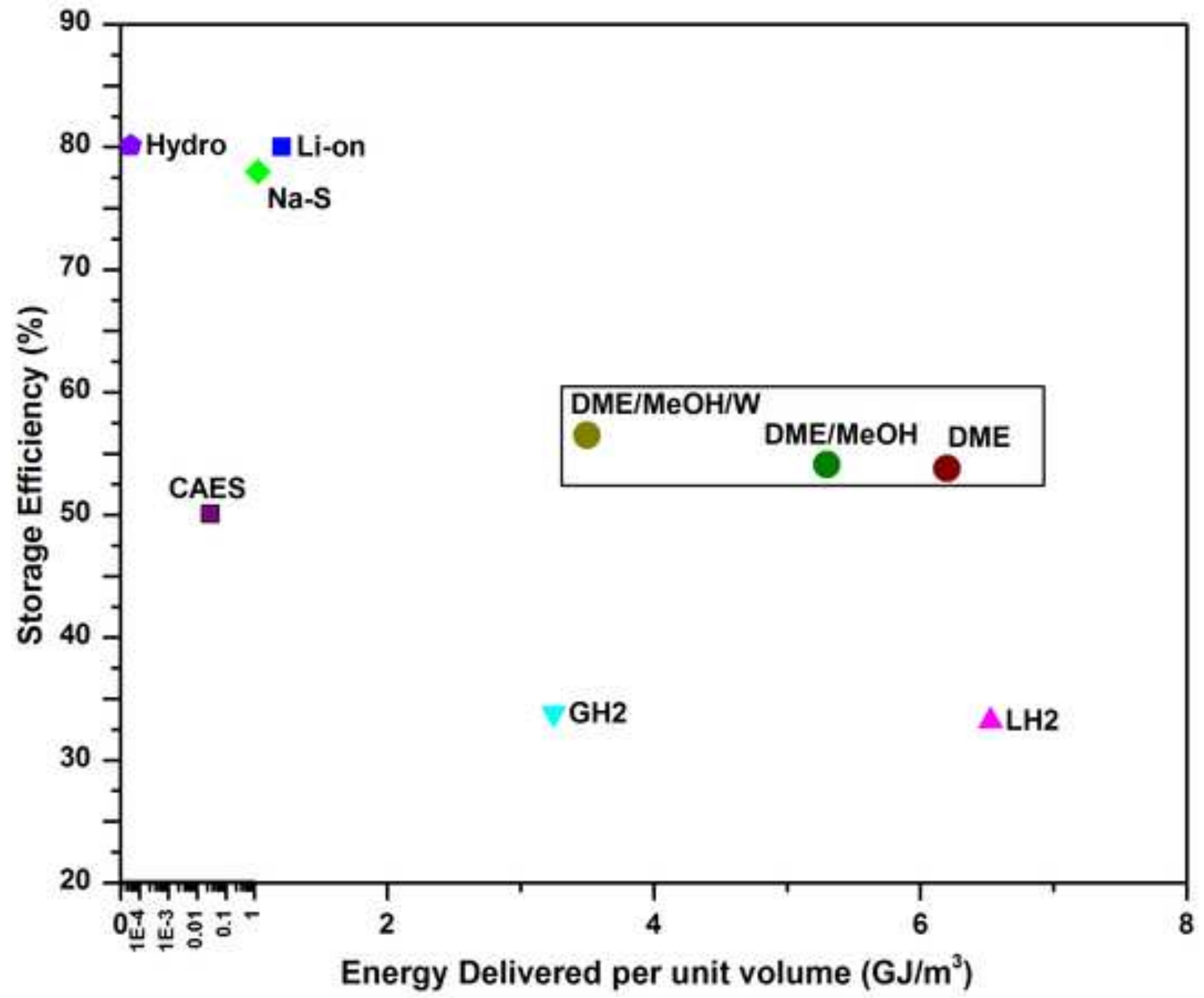




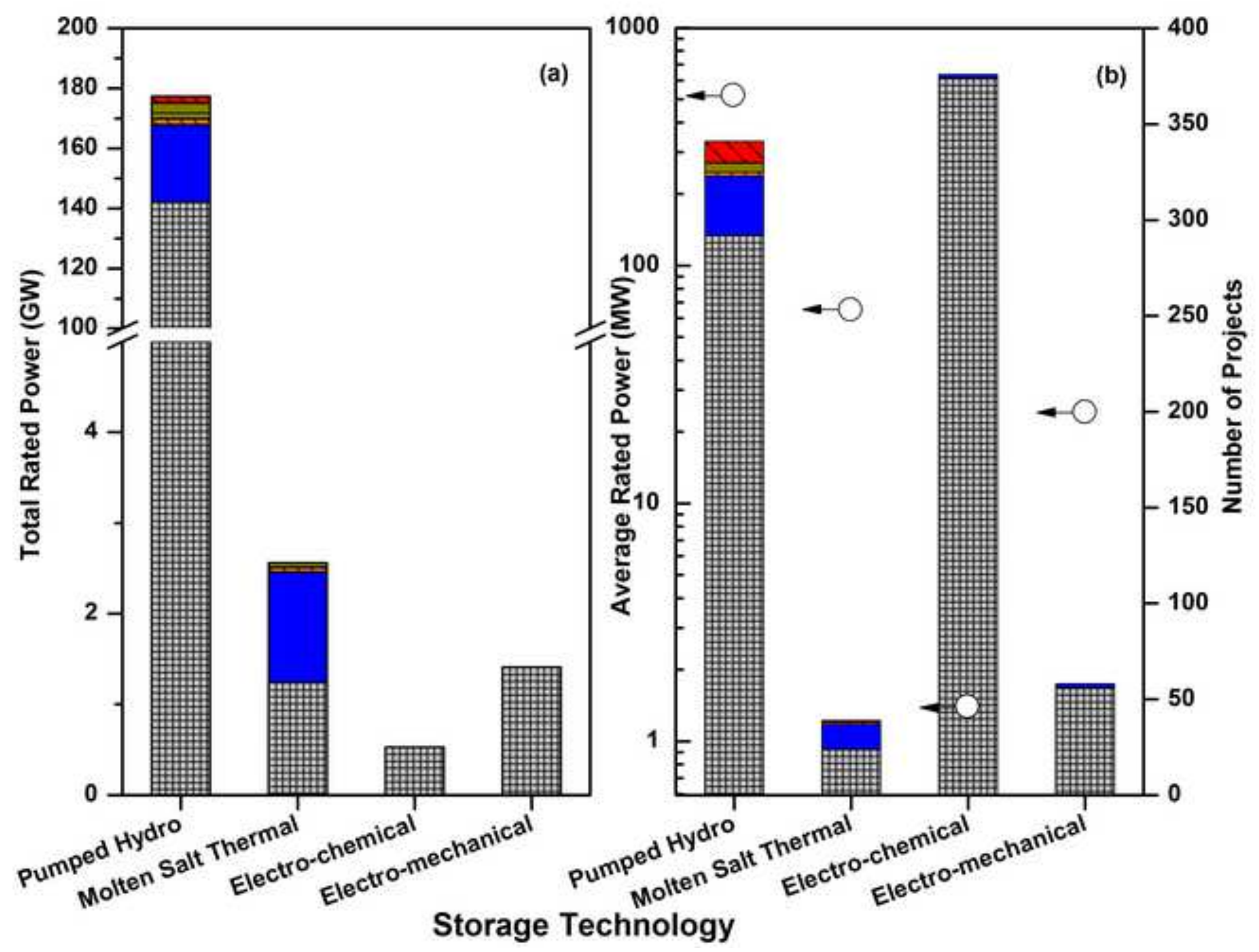




\section{Total Energy Storage Rated Power by Country (GW)}

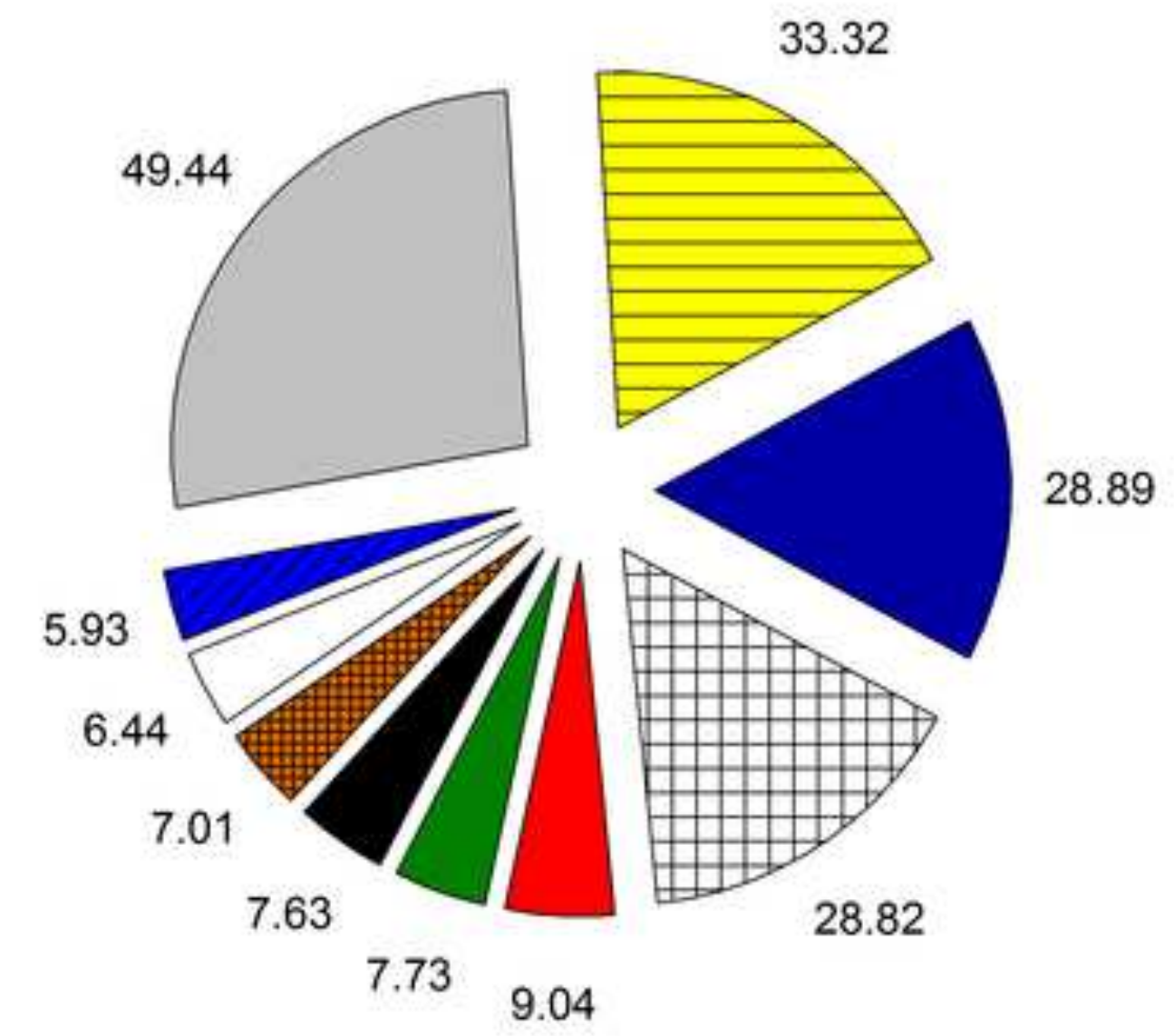

$\square$ China $\square$ US $E$ J Japan $\square$ Spain $\square$ Italy $\square$ Germany 肼曲 India $\square$ Switzerland $\square$ France $\square$ Other 


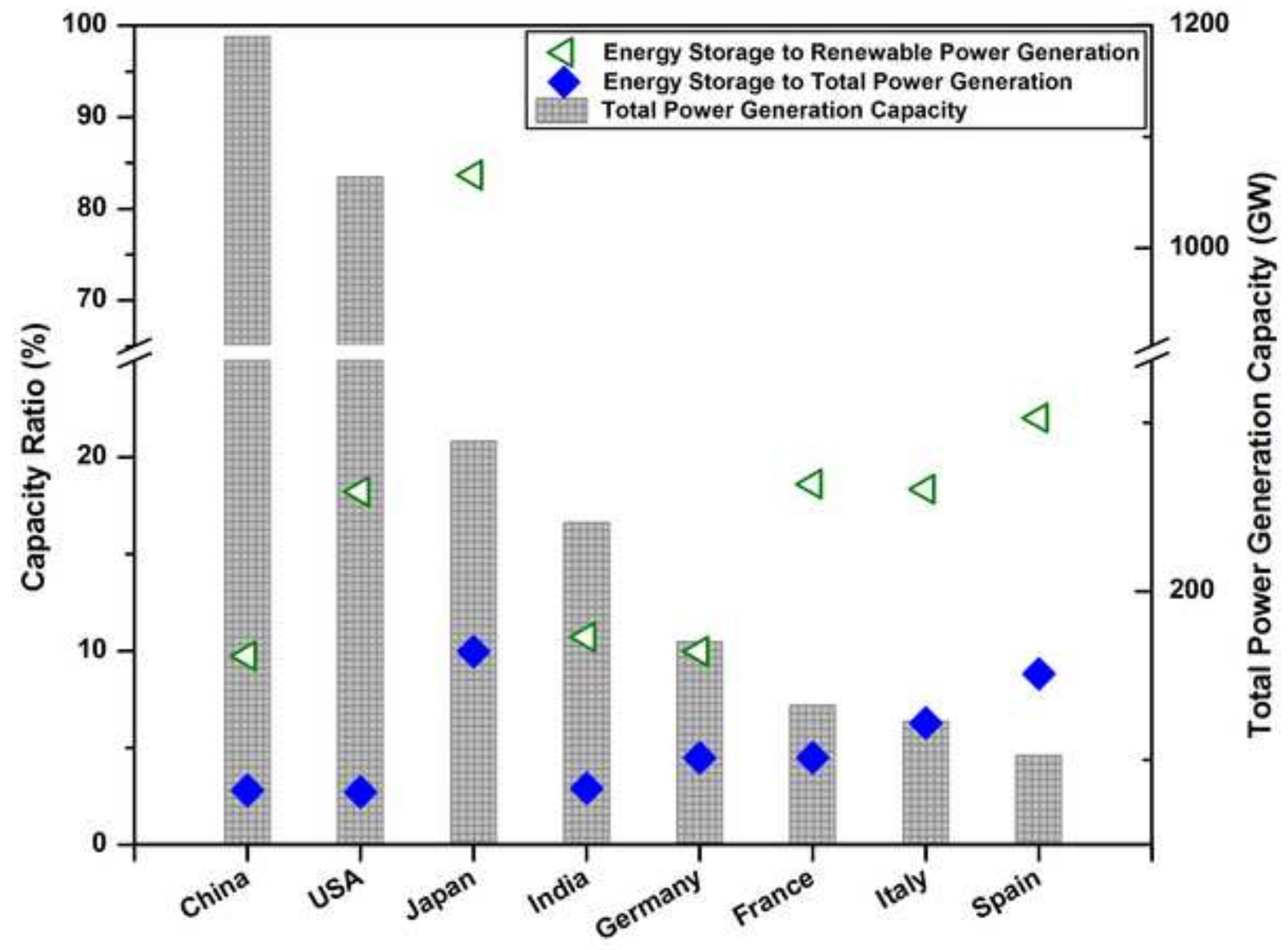




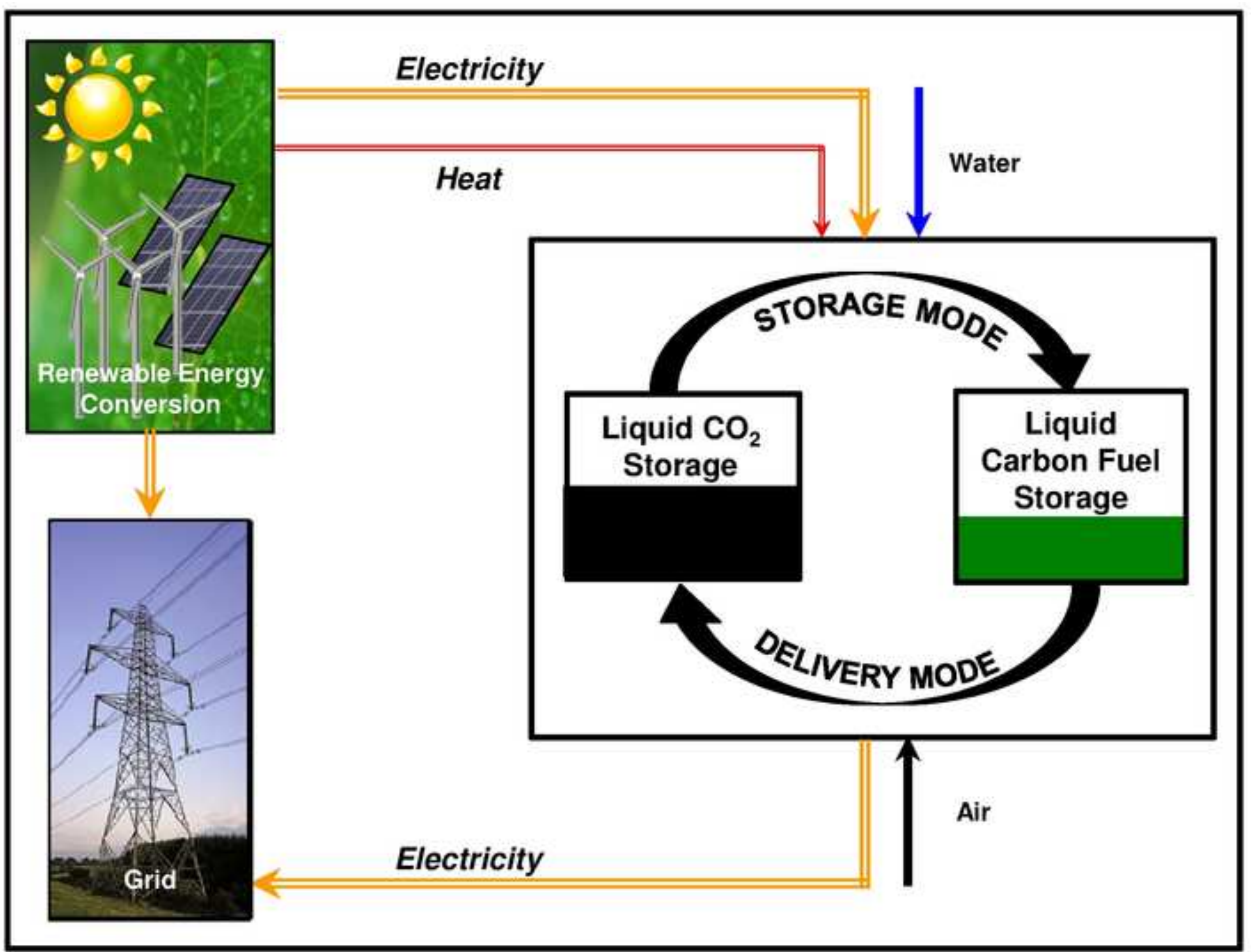




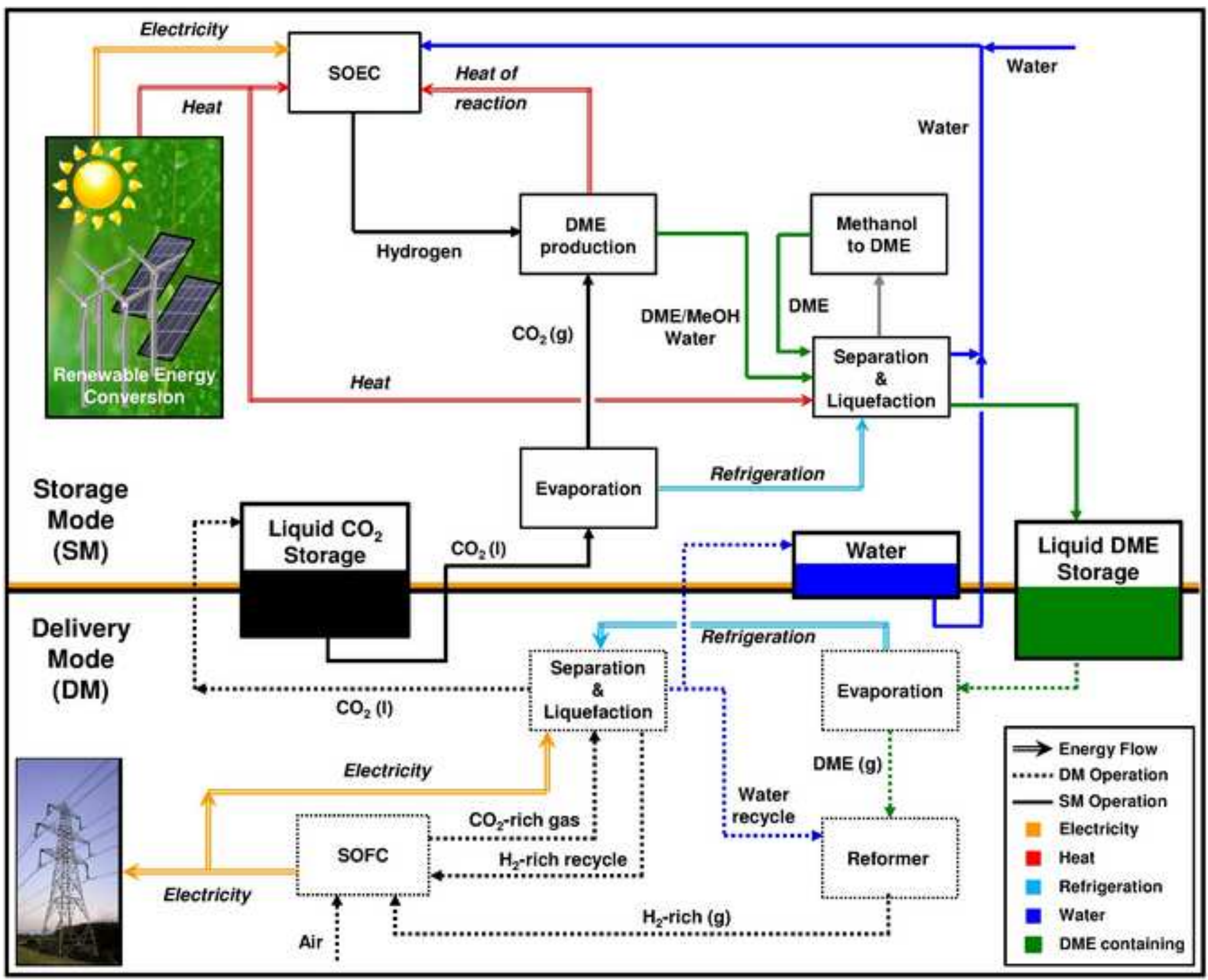


Table 1. Summary of U.S. policies and regulations

\begin{tabular}{|c|c|c|c|}
\hline $\begin{array}{l}\text { Legislative } \\
\text { and Policy } \\
\text { Measures }\end{array}$ & Objective and Short Description & Energy Storage & Status \\
\hline $\begin{array}{l}\text { Energy } \\
\text { Independen } \\
\text { ce and } \\
\text { Security } \\
\text { Act of } 2007 \\
\text { (EISA) }\end{array}$ & $\begin{array}{l}\text { Targets moving the U.S. toward greater } \\
\text { energy independence and security by } \\
\text { increasing the production of clean } \\
\text { renewable fuels, protecting consumers, } \\
\text { increasing the efficiency of products, } \\
\text { buildings, and vehicles, promoting research } \\
\text { on and deploying greenhouse gas capture } \\
\text { and storage options, and improving the } \\
\text { energy performance of the Federal } \\
\text { Government, and for other purposes. }\end{array}$ & $\begin{array}{l}\text { Section 641: United States } \\
\text { Energy Storage } \\
\text { Competitiveness Act of } 2007 \\
(\text { ESCA })\end{array}$ & $\begin{array}{l}\text { Enacted } \\
\text { in } 2007\end{array}$ \\
\hline $\begin{array}{l}\text { United } \\
\text { States } \\
\text { Energy } \\
\text { Storage } \\
\text { Competitive } \\
\text { ness Act of } \\
2007 \\
\text { (ESCA) }\end{array}$ & $\begin{array}{l}\text { Requires implementation of a research, } \\
\text { development, and demonstration program } \\
\text { for energy storage systems for electric drive } \\
\text { vehicles, stationary applications, and } \\
\text { electricity transmission and distribution; and } \\
\text { establishing an Energy Storage Advisory } \\
\text { Council. }\end{array}$ & $\begin{array}{l}\text { Most comprehensive U.S. } \\
\text { legislative measures on } \\
\text { energy storage that aim to } \\
\text { maintain development on } \\
\text { energy storage in the U.S. at } \\
\text { the forefront. }\end{array}$ & $\begin{array}{l}\text { Enacted } \\
\text { in } 2007\end{array}$ \\
\hline $\begin{array}{l}\text { Corporate } \\
\text { Average } \\
\text { Fuel } \\
\text { Economy } \\
\text { (CAFÉ) } \\
\text { regulations }\end{array}$ & $\begin{array}{l}\text { Specifies minimum standards for the } \\
\text { average fleet mileage of an automotive } \\
\text { manufacturer. }\end{array}$ & N/A & $\begin{array}{l}\text { Revised } \\
\text { in } 2011\end{array}$ \\
\hline $\begin{array}{l}\text { Clean Air } \\
\text { Interstate } \\
\text { Rule } \\
\text { (CAIR) }\end{array}$ & $\begin{array}{l}\text { Requires states to achieve specified } \\
\text { emission reductions for new and existing } \\
\text { power plants. }\end{array}$ & N/A & $\begin{array}{l}\text { Revised } \\
\text { in } 2011\end{array}$ \\
\hline $\begin{array}{l}\text { Cross-State } \\
\text { Air } \\
\text { Pollutant } \\
\text { Rule } \\
\text { (CSAPR) }\end{array}$ & $\begin{array}{l}\text { Requires states to improve air quality by } \\
\text { reducing power plant emissions that } \\
\text { contribute to ozone and/or fine particle } \\
\text { pollution in other states. }\end{array}$ & $\mathrm{N} / \mathrm{A}$ & $\begin{array}{l}\text { Impleme } \\
\text { ntation } \\
\text { schedule } \\
\text { d for } \\
2015 \text { in } \\
2014\end{array}$ \\
\hline
\end{tabular}




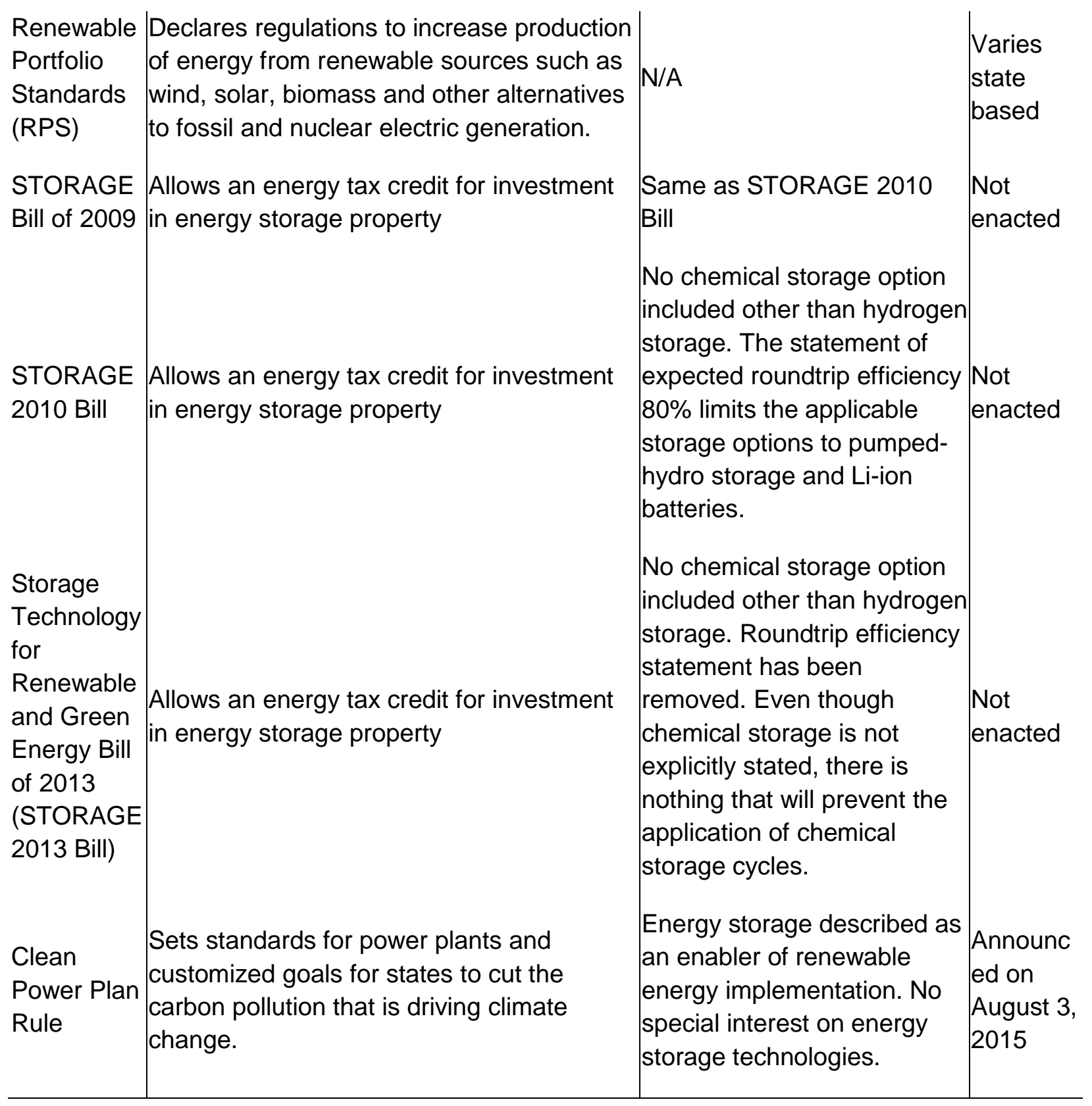

